\title{
Resource Transformation and Survival Keda as Broker in Exploitation Gold Mine in Botak Mountain Buru District Maluku Province
}

\author{
Marcelino Solissa \\ Email : marcelinosolissa@gmail.com \\ University of Gadjah Mada
}

Article Info :

\section{Article history :}

Received : August 2, 2019

Revised : September 5, 2019

Accepted : October 9, 2019

ISSN 2620-8091, Online 2620-3812

\begin{abstract}
This research, entitled "Resource Transformation and Keda Survival as Broker in Exploitation of Gold Mine in Baldy Mountain of Buru Maluku Regency". The research with the title aims to know and analyze the transformation of resources and the survival of Keda as a broker in gold mining activity in bald mountain. This research uses a qualitative research type that prioritizes case studies. Data collection techniques such as observation and interview. The elite theory and brokerage concept is used as a blade analysis in reviewing research results. Data analysis techniques are done quickly in the process of interpretation so that data that has been collected does not experience freezing or even become expired. The results of this study show that Keda transformed from the symbolic-based resources of customs and eucalyptus land to material-based resources (gold) by exploiting the illegal gold of bald mountain. In addition, Keda uses wealth as a key resource for building political networks and able to survive to respond to government policies.
\end{abstract}

Keywords: gold mine; keda; eksploitation; transformation; survival

\section{ABSTRAK}

Penelitian ini berjudul "Transformasi sumber daya dan Survivalitas Keda Sebagai Broker dalam Eksploitasi Tambang Emas di Gunung Botak Kabupaten Buru Maluku”. Penelitian dengan judul tersebut bertujuan untuk mengetahui dan menganalisis transformasi sumber daya dan survivalitas keda sebagai broker dalam aktivitas tambang emas di gunung botak. Penelitian ini menggunakan jenis penelitian kualitatif yang mengutamakan studi kasus. Teknik pengumpulan data berupa observasi dan wawancara. Teori elite dan konsep broker digunakan sebagai pisau analisis dalam mengkaji hasil penelitian. Teknik analisis data dilakukan dengan cepat dalam proses penafsirannya agar data yang sudah dikumpulkan tidak mengalami pembekuan atau malah menjadi kadaluarsa. Hasil penelitian ini menunjukan bahwa keda mengalami transformasi dari sumber daya berbasis simbolis yaitu adat dan lahan kayu putih ke sumber daya berbasis materil (emas) dengan cara mengeksploitasi emas illegal gunung botak. Selain itu, keda menggunakan kekayaan sebagai sumber daya utama untuk membangun jaringan politik dan mampu survive untuk merespon kebijkan pemerintah.

Kata kunci: eksploitasi; keda; tambang emas; transformasi; survivalitas

Please Cite This Articel As : Marcelino Solissa., Resource Transformation and Survival Keda as Broker in Exploitation Gold Mine in Botak Mountain Buru District Maluku Province : Journal of Local Government Issues (LOGOS), Doi: 10.22219/LOGOS.Vol2. 


\section{INTRODUCTION}

The existence of the elite in Indonesia greatly influences the politics, economy, structure of society, the character of social relations, and so on. As an example of the post-Soeharto local economic and political development, there is a tendency for the reorganization of power from the oligarchic group, which controls the local social and economic and political networks for their interests. Post-Soeharto local politics is characterized by the revival of past governmental entities (Karaton, Fetor, and Karaeng) and the increasingly dominant role of Local Boss, the big man in local political-economic interaction. The local elite phenomenon is also very influential in the illegal gold mining area of Balu mountain in the Buru regency of Maluku province.

The local elite called "keda" (keda originated from the Maluku language of Maluku province, which means big man) can play the role of a broker to embrace and retain power in the golden mountain of the bald island of Namlea island of Buru District of Maluku Province. The beginning of the area of the bare mountain is just a hillside overgrown with eucalyptus trees managed by indigenous peoples Wamsait Village into a local product of eucalyptus oil. The leaves of eucalyptus oil are then processed through the distillation process, and the results are sold. The management of eucalyptus oil is done by the sanusu system, which is keda employs indigenous people in Wamsait Village to plant eucalyptus oil tree with a profit-sharing scheme.

The phenomenon of keda who plays the role of a broker capable of embracing and exercising power is also found in the bald mountain gold mine on the island of Namlea, Buru Regency, Maluku Province. Namlea Island, the capital city of Buru Regency, is one of the areas producing shiny mountain gold natural resources located in Metar Hamlet, Wamsai Village, Waeapo District, which is about 30 meters from the Buru Island causeway. In the beginning, the bald mountain area was just a stretch of a hill overgrown with eucalyptus trees managed by the indigenous community of Wamsait Village to become a local product of eucalyptus oil. Eucalyptus oil leaves are then processed through the distillation process, and the results are sold. The management of eucalyptus oil is carried out with the sanusu system, namely the keda employing the indigenous community members in Wamsait Village only to plant eucalyptus oil trees with a profit-sharing scheme. Eucalyptus oil is one of the livelihoods of indigenous people in this area who work as eucalyptus tree farmers and eucalyptus oil processors including the local elite

In May 2011, a gold mine was found in the Balinese villagers of Wamsait customary village by Susyono, which started from a dream. The existence of this gold mine which became the starting point of transformation keda that influential and had an important role. People around the area slowly start doing the gold search activity around the area of the bald mountain as diggers and miners of gold by using implants from the cauldron (frying pan) that he bought from the market and then sell it to the penada or buyer. In managing the bald mountain gold mine, there are three significant clans as policymakers in the exploitation of the gold mines of Wael, Nurlatu, and Besan. In addition to the indigenous communities of Wamsait Village, there are also gold seekers (migrants) from Kalimantan, Java, Sulawesi, Sumatra, and Maluku.

The existence of a gold mine on a bald mountain raises the power of ordinary people who have rights over customary lands or petulant such as conventional heads, legendary figures, and indigenous peoples. Usual leaders and traditional values initially only carry out their duties and authorities to take care of the boundaries of the land, perform traditional ceremonies, resolve traditional disputes, adat marriages, other customary administrations, and control the natural resources of eucalyptus oil to transform into brokers authority over tenure and customary land ownership in gold mining activities. The purchase of the customary land makes the keda a broker and can network using the patronage system (patronage).

Please Cite This Articel As : Marcelino Solissa., Resource Transformation and Survival Keda as Broker in Exploitation Gold Mine in Botak Mountain Buru District Maluku Province : Journal of Local Government Issues (LOGOS), Doi: 10.22219/LOGOS.Vol2. 
This gold mining commodity changes the relation of keda and indigenous people of swimsuit village with local government. Before the existence of the bald mountain gold mine, indigenous peoples and keda have always followed government policies, but government policies related to the closure of the bare mountain got rejected. Keda, who owns the golden landholders, has the power to grant permission and employ miners to mine gold. Every miner permitted to enter the bald mountain gold mine should use futon (in Buru means a meaningful head lens as a customary person). The proceeds from gold mining are divided between the miners and the kids. In addition, the keda also collect charges from motorcycle taxi drivers and deer (material bearers). When compared with the management of eucalyptus oil resources, then the results obtained from the gold mine are more excellent.

In its development, the broker not only gives permission and employs the miners but his power affects the local government policy in the process of closing the illegal gold mine in the area of the bald mountain so that the State in this case the local government is weak in implementing the provisions contained in the Decree (SK) of the Governor of Maluku about the closure of gold mining activities botak mountain.

\section{LITERATURE REVIEW}

Local elites in Papua emerge and respond to government policies, namely local elite groups that depend on government policies supporting Papua autonomy which are supported successfully, and also elite groups that are outside the particular government structure, and even local elites oppose individual independence in Papua. Second, the attitude of local elites who are very dynamic in responding to the specific autonomy policy is influenced by factors rational choice factors, tribal factors, and solidarity that support the contestation of Papua and Papua (De Fretes 2015).

The building of power relations between tauke, skipper, and bandol in the process of orientation on the mere dredging of profits, also experiences the species of resources owned by each person that forms a power relation between them in the structure of the tobacco trade. Some actors are also involved in the political world, such as the elections and the presidential election. On the other hand, there are regional regulations governing tobacco trading that are unable to touch the root of social problems that develop in society, especially grassroots farmers (Zamroni 2007).

Politicians and entrepreneurs in the DPRD and the administrative executive of the OKU regional government are placed as interdependent local state actors related to informal networks that frame the practice of the predatory state (Mahsun 2013). The dominance of politicians and business groups in the district legislature created a system of political patronage and cronyism relations with entrepreneurs who framed the rapacious rule of the state in the process of regional budgeting development. There is piracy by politicians and entrepreneurs who conspire with the executive elite in the process of budgeting, transactions, and exchanges between groups of business politicians and entrepreneurs who are in a relationship of patronage and cronyism (Mahsun 2013).

The results of the study explained that the socio-economic and political context in Rembang Regency strongly supported the emergence of clientelism practices and the presence of brokers in the company. The existence of a broker can carry out four tasks and functions, namely the function of mediator, drafter, mediator, and distributor. The purpose of the broker gets four driving elements, namely: instruction, information, resources, and loyalty. The existence of the broker as a determinant of the asymmetrical, personalistic, iterative, and reciprocal principles between patron and client.

Bhejingan in Madura playing an essential role in the process of village head elections (Romadhan 2018). Bhejingan is a cultural designation for Madurese who work like thugs. It was this strength that made his 
position so powerful that it was used by the would-be village head to mobilize voters through money politics (Romadhan 2018). Their activities have proven to reduce democracy because of intimidation and violence towards voters.

The formation of the Helsinki MoU, which subsequently gave Aceh great political privileges, gave birth to an institution called Wali Nangroe. In the structure of Acehnese society, Wali Nangroe is highly respected so that it becomes Malik Mahmud's strategic capital to transform himself into an influential political elite in Aceh's governance and also deserves to be categorized as Local Strongmen (Akbar 2019). This paper looks at the presence of Malik Mahmud thanks to state intervention through opportunities and legal standing.

Botoh's practice in the selection of village heads in Kota Batu 2018. Botoh was associated as local bossism. Botoh uses village head elections as a gambling arena to increase capital accumulation and strengthen political patronage. BDRT as a botoh as well as a local strongmen became a broker of votes for certain candidates. BDRT is not a formal actor of power, its orientation is only to ensure its non-formal power structure continues stable (Romadhan, Khanifah et al. 2019).

The novelty of this research is analyzing the transformation of resource resources from symbolic to the material. Researchers use the theory of "elite" to explain and answer the dynamics that occur, namely the change of symbolic resources (indigenous peoples) into material resources by exploiting the exploitation of gold mines in the area. In the exploitation of extractive resources (gold) in the bald mountains of Buru, Maluku, Keda plays an essential role in the exploitation of gold mines, namely granting permits to enter mining areas, employing miners, renting drum machines for the process of separating gold from rocks and building political networks with other actors who have an interest in making a profit.The existence of keda in the exploitation of gold mines in the bald mountains of Buru Regency, Maluku, most of them has a background in life as indigenous peoples who have eucalyptus tree land. However, with the discovery of gold in the bald mountain then slowly the keda transformed into a broker that was very influential in exploitation. With the gold resources owned by the keda, its position is getting stronger in social structures, exploitation of gold mines, surviving as a broker in responding to government policies regarding the closure of a gold mine, surviving, and being able to demonstrate its existence in electoral politics.

\section{METHODS}

Data analysis techniques are carried out quickly in the process of interpretation so that the data that has been collected does not experience freezing or even becoming expired. This study also uses qualitative methods to manage and analyze data. In general, qualitative methods are research methods that directly or prioritize field observations with social cases. The results of this study indicate that the keda transformed symbolic-based resources, namely adat, and eucalyptus land to material-based resources (gold) by exploiting illegal gold in bald mountains. Besides, the keda uses wealth as the leading resource to build political networks and can survive to respond to government policies

\section{RESULTS AND DISCUSSION}

\section{Keda Resources and Electoral Politics}

Local hunting peoples consume the eucalyptus oil as a source of the community economy. Oilproducing eucalyptus farmers are a remote indigenous community with a farming background. The eucalyptus oil refinery farmers have local knowledge and wisdom in managing natural resources, especially eucalyptus crops, through simple technology (traditional) from generation to generation to produce high-value economic eucalyptus oil. The community also promotes eucalyptus oil as a local 
hunting island commodity. Data obtained by the Indonesian Central Bureau of Statistics in 2006 explained that Buru Island is the largest producer of timber crops in Indonesia. Buru island's natural wealth resulting from the management of eucalyptus crops has been around for hundreds of years. The results of the selling of eucalyptus oil sold at Rp.120.000 per bottle is not only used by the community to meet the daily needs but also the cost of children's education.

After the opening of the illegal gold mining process on bald mountain in 2011, the villagers of the swimsuit began to turn the profession as miners. Besides, keda experienced resource transformation and played a double role as a broker in the exploitation of the illegal gold mine. The strength of the broker in the exploitation of gold mines is by using the client patron system. Clientparton systems involving security forces as well as entrepreneurs, bureaucratic actors engaged in the exploitation of the shaft. By accumulating the strength of the brokers to survive.

Profit broker obtained from entrance fee Rp. Five hundred thousand per three months, gold mining and trommel tool rentals are more significant than the results obtained from the distillation and sales of timber oil. Brokers cultivate wealth and power by networking with local actors as well as migrants who take advantage of exploitation in the gold mine. The existence of brokers as policymakers strengthens its position as a decisive elite in the society's destruction.

The presence of keda as a broker is also able to influence the electoral politics of the Buru district. These electoral political changes include the New Order era. In 1969 the Indonesian government designated the island of Buru, especially the weapon area as a political prisoner G $30 \mathrm{~S} /$ PKI, so political rights were limited. Reform era With the enactment of Law number 32, the year 2004 gives space for local government to freely arrange their household to provide space for kids to show its existence in electoral politics at the local level.

\section{Electoral Politics and Composition of Power in Buru Island}

The political context at the local level opened up a new phase of power dissemination in the harsh district of Maluku province. The democratic party of the regional head election in 2012 which is following the result of the determination of the local general election commission, which decided and set Ramly Ibrahim Umsugi as the head of the hunting district. Interview conducted on July 7, 2017, at the same time with Dirhan Umasugi as the winning success team Ramly Umasugi stated that Ramly Umasugi's victory could not be separated from the support of the then ruling party in Golkar.

The Golkar Party dominates the influence of political party power on the democratic party in the 2012 Buru Regency. Ramli umasugi from the Golkar party managed to steal the hearts of the community in an open campaign with its various programs. On the other hand, Ramli umasugi's track record that started his early political career as a member of the DPRD two periods (2000-2004) and (2004-2009) later became bupati in the year (2007-2012) recommended from the Golkar party at that time.

In 2017 the Golkar Party again gave recommendations to Ramly Umasugi in the democratic party election of regional heads in Buru district. The position of the head of Buru regency was still occupied by rally umasugi based on the decree of the district election commission number 41 / kpts / KPU.Buru / 029.433 / II / 2017 on the Stipulation of Recapitulation of the Result of Vote Acquisition and Election Results of Regent and Vice Regent of Buru Regency Year 2017. Thus the power base of Golkar political parties still dominates the party democracy of regional head elections in Buru district.

Local political struggles in hunting districts are not only at the level of political parties as legislative vehicles in democracy parties, but political rivalries in hunting areas are also seen with the 
ambitions of advanced political actors and competing in democratic parties. Family politics in the nomination of regional heads in 2017 is visible on PPP's family relations in determining the recommendation for the appointment of the local leader. Chairman of the PPP DPP of Buru regency Aziz Hentihu who chose to resign in the struggle for the PPP party's recommendation because of his cousin Amirulah Madani Hentihu's cousin who is a member of Parliament Buru also participated in the regional head arrest and even in the advice of the PPP party. Thus the power and role of political parties in hunting districts can play their part as political machines by local political actors in seeking the benefit of specific groups as well as in the outer circle of the actors.

Based on observations made by researchers on 24 April 2017 in Buru district that local political power can be seen with the presence of a number of families from the regents of Ramly Umasigi who occupy strategic positions in the government bureaucracy Kabupaten Buru, Irvan Uasugi who served as kabid Humas Protocol of Buru district, head of the Badab human resources department of Efendi Rada, members of the DPRD Buru from the golkal faction Fandi Umasugi and Syahran Umasugi. Family politics played by the Umasugi family make them essential position holders in the political machinery of hunting districts. The result of interview with Robbi Nurlatu on 21 April 2017 that Ramly Umasugi's success in the head of hamlet district is also inseparable from the support given by the nurlatu clan in wamsait village. Political deals are being played to hold full power in the local political sphere in hunting districts.

\section{Transformation Keda and Exploitation of Gold Mine}

The life of indigenous peoples of wamsait village experienced a change in behavior, livelihood, social, and economic relations when the discovery of a gold mine on a bald mountain. The activities of indigenous peoples of wamsait village who formerly worked as farmers of cultivation and cultivation of eucalyptus oil transformed into miners and gold producers.

The role of keda in the eucalyptus oil (local economy) activity is as the landowner who employs the surrounding community in the eucalyptus tree with a profit-sharing system and resolves the customary land dispute and indigenous movements within the indigenous population. The role of brokers in gold mining activities is as a regulator and policymaker in mining activities and provides entry permits for miners and sellers. Brokers are also capable of controlling security in gold mines such as conflicts between the ambalau community and the miners in the bald mountain. Brokers have a significant influence on miners and buyers in deciding policies, offering, mediators, and intermediaries. Brokers can also position themselves as patrons but also clients. When the broker positions itself as a client in gold exploitation activities, then the patron is the security, bureaucratic elites, and entrepreneurs. But when the broker positioned himself as a patron, then his clients are the gold miners and buyers. The implications of the role of brokers in social life have not changed significantly. Keda continues to function as an indigenous person to secure his position as a patron in the exploitation of the gold mine.

\section{Survival Keda In Closure Of Gold Mine In Botak Mountain}

Symbolic resources possessed by keda before the bald mountain gold mining are the status of indigenous people, customary land ownership, and eucalyptus tree land. The condition of indigenous people has a vital role in the settlement of cases related to customs such as conventional land boundaries and marriage. Indigenous land ownership, which was initially overgrown with eucalyptus oil trees, had little influence over the power of local elites. The eucalyptus tree plantation is used as a producer of local commodities, and the advantages of eucalyptus processing turn the economy of society better. The success of keda in the exploitation of natural wealth in the bald mountain can

Please Cite This Articel As : Marcelino Solissa., Resource Transformation and Survival Keda as Broker in Exploitation Gold Mine in Botak Mountain Buru District Maluku Province : Journal of Local Government Issues (LOGOS), Doi: 10.22219/LOGOS.Vol2. 
improve the material source. The luster of treasures then led to the peak of its glory in mining activities. Wealth is not only in the form of money but also the assets of the gold mining of bald mountain.

\section{Keda Biography}

Robby Nurlatu is an indigenous people living and living in the wamsait village of Wayapo district Buru district, who has a position in the customary structure as a legendary figure in the town of wamsait. Marga Nurlatu who inhabited the Wayapo region based on the distribution of ulayat rights in the village. Ownership of land in tumbuhi eucalyptus trees make the surrounding community began to take advantage of eucalyptus trees as a local product for the economic needs of the city. The result of the processing of eucalyptus oil products only to meet daily needs because the processing of eucalyptus oil takes a long time and long. Ownership of eucalyptus land can not be compared with the gold mining results obtained. The yield of eucalyptus oil also has not been able to boost up the social strata in society and increase the community's economy if compared with the income generated from the exploitation of illegal gold mine.

The change occurred to the indigenous people of the village of Wamsait sub-district wayapo Buru district with the discovery of a gold mine in the bald mountain, including the actual figures who have the customary land rights in the bald mountain. The economic shift of society is seen when gold mines in the bare mountains begin to be exploited illegally. The community economy is slowly increasing with the existence of the illegal gold mine. Landowners also experience a shift in income and material wealth from what was once dependence on the production of eucalyptus oil, which is a local product in the hunting district shifted to the wealth resulting from the exploitation of illegal gold mines in the bald mountain.

The shift is not just concentrated on wealth alone, but the change of power that exists since the exploitation process takes place. The transformation was evident when the Nurlatu clan took an essential role in the illegal mining activity. Life and social status within the community are slowly positioning itself the highest in society due to the unlawful land ownership of the gold mine on the bald mountain. The bare mountain gold mine also shifts and changes the life of Robbi Nurlatu as one of the traditional leaders in the village of Wamsait. Wealth can change the strata social in life. Initially, Robby Nurlatu joined the political party in 2012 with a democratic political party, which as one of the parties that became a forum for learning about politics and participating in the team of Pemu elections head of district Buru district in 2017 which memenagkan Ramli umasugi as regional head. Robby Nurlatu began to show his existence in local politics in the hunting district by joining the PKP political party by occupying the position as the secretary of DPK (district leadership council), the justice party, and the unity of hunting district of Indonesia. Robby's participation in party stewardship opens a new stage where kids also begin to show the existence and power in the political sphere. Involvement in political parties can not be separated from the wealth of exploitation of illegal gold mines in the bald mountain.

Physical existence Robby Nurlatu also seen when his involvement in replacing political parties as a political vehicle to advance in the party democracy is by joining the Party Nasdem. Interview conducted by Robby Nurltu explained that his involvement as a cadre Nasdem is not something that limits his political rights because anyone can move or change the party following his wishes. The process of moving from the PKPI party to Nasdem was denied by the PKPI party experiencing internal party shocks at the national level, thus making it transfer to the Nasdem party. Therefore can be drawn red thread from the results of interviews related to the track record keda Robby who menunukan existence in local politics and also able to play the role of political fleas where Robby nurlatu even start mengabungkn self with national party democrat (Nasdem) this is new phenomenon

Please Cite This Articel As : Marcelino Solissa., Resource Transformation and Survival Keda as Broker in Exploitation Gold Mine in Botak Mountain Buru District Maluku Province : Journal of Local Government Issues (LOGOS), Doi: 10.22219/LOGOS.Vol2. 
for keda that is with the wealth possessed capable of playing a double role in the local political sphere.

Then it can be deduced from the exposure biography keda Robby nurlatu that the shift of resources owned will result in the position of a person experiencing changes in the social strata of society with the wealth of a person can easily do what he wants. Power and the power network relationships that are owned as political capital.

The role of the local government of Buru Regency in closing the bald mountain gold mining activities is following the regulations; if the law gives space to the government, then the government will act following the rules of the game. The local government of Buru Regency has adopted a policy of 25 times to cover the activities of the Balinese gold mine due to environmental pollution from the cyanide and mercury gold processing wastes, but the gold mining activity remains silently undertaken. Thus, the authority related to the closure of the gold mining activities of the bald volcano has been transferred to the provincial government. The issuance of Governor Decree number 552-1 dated December 11, 2013, about the closure of the mining site and the arrangement of the Maluku bald mountain area about the cessation of gold mining activity bare, indirectly open network with TNI and POLRI using patron-client system network. Security forces in illegal activities in which the presence of security forces in charge of safeguarding mining activities is exploited by keda as the guardian of hidden miners' activities from the keda. The keda builds good relationships with the military district commander in Buru District so that operations are conducted in private and can be guarded by security personnel, ie, the activity of transporting materials from bald mountains to gold or trommel processing plants.

Thus illegal gold mining activities indirectly put keda as a boss and security apparatus as a protector in unlawful activity. The presence of the security apparatus provides a space for keda to remain to survive and to assume the role of ruling that there is a defining position in the illegal activity.

The bureaucratic politicization system does not only take place at the Buru Regency level but at the provincial level it also involves the head of Maluku provincial government who is also engaged in playing its role in granting licenses to entrepreneurs through companies licensed by the provincial government in this field of ESDM to manage the gold mine in the going bald. The involvement of keda in political networks is broader and broader not only at low levels but also at higher levels. There is no firm, consistent, and transparent set of rules and policies governing mining operations, including licensing, coaching, liability, and sanctions. The weak understanding of the local government apparatus in the knowledge of good mining practices and the behavior of devices seeking personal benefits over illegal mining activities is an essential factor in the growth of illegal mining.

Keda also builds political relationships through proximity to communities where the material wealth possessed by keda is donated for the development of self-help communities around, among others, donations for the construction of mosques, church construction, and gifts for certain kampung or desa, kinship keda brotherhood between people basudara language the Buru people is a relation of brother to political politics to accumulate votes in the electoral process.

On the other hand, political proximity and access to political power keda begin to enter student organizations from certain villages or kampung as the electoral area of the keda. Donation and assistance in the form of money to student organizations as a reciprocal relationship between students and students when the legislative election process takes place

Comparison of the dynamics of the role of the local elite in the 2010 Bima regional election conducted by Septi Setriani, et al. explained that the local Bima elite who "fought" in the 2010 Bima local election identified from the aspects of power and role. Research in Bima found that every elite involved in the post-conflict political election process had their genealogy, networks, interests, and

Please Cite This Articel As : Marcelino Solissa., Resource Transformation and Survival Keda as Broker in Exploitation Gold Mine in Botak Mountain Buru District Maluku Province : Journal of Local Government Issues (LOGOS), Doi: 10.22219/LOGOS.Vol2. 
parts. Elite Bima, which shows elite genealogy, function, position, and status of the elite, experienced formation status according to the context of the political power of the era with a royal background. For example, the victory of Ferry Zulkarrnain is inseparable from the title of the empire he had. The sultanate's title is still an essential factor for people who have emotional ties with the kingdom. The existence of the Bima sultanate figure is an attraction for the people of Bima. The character of the king's grandson was then packaged in such a way by his success team as a kind of brand image for Ferry.

The history of the Bima elite then influenced the structure that underlies today's elite competition. The post-conflict local election arena is a place where elites compete in power with the liberalization of resources. These local elites are indeed not entirely new figures, but they have already had access to material resources and also have access to control the "instruments" of political violence

Material sources as a result of the bald mountain gold mine owned by local keda elites made them begin to show their existence to fight in local politics (pileg). The local keda elites who were involved in local politics had networks and interests that were built at the time of the exploitation of the gold mine on the bald mountain.

According to Hadiz, although this centralized system no longer exists, the elements have reorganized themselves in a new patronage network that is decentralized, more fluid, and competes with each other. Even the range of interests that are now competing for power at the local level seems more varied than in the Suharto era. These included ambitious political brokers and dealers, skilled and still predatory state bureaucrats, new high-ambitious business groups, and a variety of political gangsters, criminals, and civil security forces. The old regime raised most of these groups as their field operators and implementers.

So according to the authors, the survival of the local elite in the closure of the bald mountain gold mining activities was carried out with a patron-client political network system that was mutually beneficial and opened a network with formal and informal actors. Also, the survival and network system as a resource to show the existence of local elites keda in local politics (pileg) like the local elite in Bima. Thus, the local elite has succeeded in accumulating the power they have so that they remain in the top position as the determining elite.

\section{CONCLUSION}

So obtained the following findings:

1. Keda transforms several aspects:

a. The transformation of the eucalyptus oil (petuanan and cassava tree) resources to illegal (symbolic, material, and social) gold mines.

b. Keda performs the role before the gold mine is taking care of the boundaries of the land, performing traditional ceremonies, resolving customary disputes, adat administration, and hunting. With the illegal gold mining of the bald mountain, the role of keda also undergoes a transformation, which acts as a broker (intermediary between seller and buyer), builds a political network, performs social action, and performs duties as customary structure.

c. With the wealth that both belong to the exploitation of the bald mountain gold mine into the capital to compete in local politics.

2. The exploitation of the gold resources of the bald mountain gold gives space and opportunity to keda with power to respond to government policy in the process of closing the illegal gold mine in the bald mountain. The weaknesses of local governments in handling illicit mining activities in the bare mountain because of the parties or elements of the government and the security side who took part 
and played a role in the exploitation of illegal gold mines in the bald mountain for individual interests and interests of specific groups who are equally wriggling profit. By using political networks, Local bosses (keda) successfully accumulate full power over the exploitation of gold mines in bald mountains and take an essential role in policymaking. The big boss occupies a specific position in the gold mine because it can not be separated from the actors or followers of keda as a protector.

3. The existence of keda in local politics in hunting districts can be seen with the wealth generated from the exploitation of illegal gold mines as material capital for entry into political parties. On the other hand, keda is also able to improve the politics of jump fleas in choosing a party to strike itself as a member of the legislature.

Of several reports in the field findings related to exploits illegal mine in the boy, a conclusion can be drawn that the existence of the local ( keda ) having might be able to control and respond to the presence of the state in an activity illegal mining. The life of keda also turned the role and function is a country that possesses rights in the process of making policy has not been able to local. mentor the presence of the elite.

\section{REFERENCES}

Akbar, A. (2019). "Malik Mahmud Local Strongmen?" Journal of Local Government Issues 2(1): 38-50.

De Fretes, D. R. (2015). Sikap Elit Lokal Dalam Merespon Kebijakan Otonomi Khusus Papua Universitas Gadjah Mada.

Mahsun, M. (2013). Local Predatory Elite? Potret Relasi Politisi-Pengusaha Dengan Penguasa Studi Relasi Politisi-Pengusaha di DPRD dengan Elite Eksekutif dalam Penganggaran Pembangunan Infrastruktur di Kabupaten OKU Pasca Pemilu 2009, Universitas Gadjah Mada.

Romadhan, A. A. (2018). "The Role of Bhejingan in The Selection of Village Chief." Journal of Local Government Issues 1(2): 244-269.

Romadhan, A. A., et al. (2019). "The Role Of Bossism In Practice Of Gambling Election Of Village Head In Batu City." Prosiding ICOGISS 2019: 899-909.

Zamroni, M. I. (2007). Dinamika kekuasaan elite ekonomi lokal pasca Soeharto di Pamekasan Madura:: Menguak relasi kekuasaan antara Tauke, Juragan, Bandol dan Kiai dalam perdagangan tembakau dan pentas politik di tingkat lokal, Universitas Gadjah Mada. 